\title{
Evaluace program Ekoškola
}

\section{Jan Činčera}

\section{Envigogika 2008/III/ 2 - Recenzované články/ Reviewed Papers}

Publikováno/Published 22. 12. 2008

\section{DOI: http://dx.doi.org/10.14712/18023061.30}

\begin{abstract}
Abstrakt:
Článek prezentuje výsledky výzkumu zaměřeného na evaluaci programu Ekoškola. Výzkum porovnával znalosti, postoje a chování žáků škol, které získaly zelenou vlajku, se školami, které nově vstoupily do programu. Evaluace se týkala dvou skupin studentů - studenti školy, která získala „zelenou vlajku", byla srovnána se skupinou ze školy kontrolní. Zkoumání se týkalo znalosti akčních strategií, akčních dovedností, víry ve vlastní možnosti, školního klimatu a proenvironmentálního chování. Článek je rozdělený do dvou částí: v první popisuje metodiku evaluace, ve druhé prezentuje výsledky.
\end{abstract}

\section{Klíčová slova:}

$\mathrm{XXXX}$

\begin{abstract}
:
The article presents results of a research focused on evaluation of the programme Eco-Schools. The evaluation strategy was based similar research conducted in Ireland. In the evaluation two groups were compared: the experimental, created by students of the 7th grade from schools awarded by the Green Flag, and the control, consisted of students of schools which recently launched the programme. The main dependent variables were knowledge of action strategies, action skills, internal locus of control, school social environment and pro-environmental behaviour. The research revealed significant differences between group in the field of knowledge, locus of control and behaviour, while not showing differences in action skills and school social environment.
\end{abstract}

\section{Key words:}

$x x x x$ 


\section{Základní informace o programu}

Ekoškola (Eco-School) je program mezinárodní neziskové organizace FEE (Foundation for Environmental Education). Byl vyhlášen $v$ roce 1995 jako reakce na Summit Země $v$ Rio de Janeiro $s$ cílem zapojit mladé lidi do hledání řešení pro udržitelný rozvoj. Po rozšíření v Evropě se projekt díky podpoře UNEP a Evropské komise dostal i do dalších regionů, zejména do Afriky (program je velmi populární např. v Jihoafrické republice), Latinské Ameriky, Oceánie a východní Asie. V roce 2006/2007 probíhal ve 40 zemích světa a účastnilo se jej přibližně 21000 škol (FEE, 2003).

V České republice je program na národní úrovni koordinován Sdružením TEREZA, regionálními koordinátory jsou střediska ekologické výchovy Divizna a Lipka. V současné době je do něj zapojeno 211 škol (184 ZŠ a 27 SŠ), z toho 42 získalo "zelenou vlajku" a titul Ekoškola, přidělované školám splňujících standardy programu. Program je určen pro první i druhý stupeň ZŠ a pro střední školy (Sdružení TEREZA, 2007; Sdružení TEREZA, 2008).

Cílem programu je, aby žáci prostřednictvím své práce ve třídě a na školních či komunitních akcích zvýšili své porozumění environmentálním problémům. Program současně poskytuje integrovaný systém pro školní management založený na normách ISO14001/EMAS (FEE, 2003).

Prostředkem $\mathrm{k}$ dosažení cílů programu je zapojení dětí do procesu snižování environmentálních dopadů školy (FEE, 2003). Žáci vytváŕí ekotým a společně s pedagogy postupují $v$ sedmi navazujících krocích, které tvoří jádro metodiky programu (Sdružení TEREZA, 2007).

Školy, které splní všech sedm kroků na úrovni odpovídající zveřejněným kritériím, mají právo zažádat o obdržení titulu Ekoškola, který platí dva roky a je symbolizován zelenou vlajkou. Titul získá škola, na které proběhne úspěšně audit, který prověruje dosažení stanovených kritérií (Sdružení TEREZA, 2008).

\section{Základní rámec evaluace programu Ekoškola}

\section{Cíle evaluace}

Cílem prezentované evaluace je porozumět fungování programu Ekoškola. Přestože dopady programu na ekologizaci provozu škol jsou měřitelné a měřené, není jasné, do jaké míry program ovlivňuje samotné žáky a tyto výstupy nejsou ani přesně specifikovány. Pro potřeby evaluace je proto nutné nejprve očekávané výstupy programu navrhnout $v$ podobě hypotéz, které budou dále ověřovány. Na jejich základě pak bude možné specifikovat výstupy programu a otevř́t tak prostor pro jejich podrobnější evaluaci.

Předkládaná evaluace je prvním pokusem o vyhodnocení programu $v$ České republice. Jako taková si neklade ambice na jeho komplexní analýzu. Předpokládáme, že na její výsledky bude možné navázat $v$ dalších doplňujících šetřeních, které prezentované výsledky potvrdí, vyvrátí, rozšírí či jinak modifikují. Těmi jsou v době publikování tohoto článku především rozpracovaná kvalitativní evaluace programu, zaměřující se hlavně na vybrané otázky souvisejíć s jeho dopady na školní klima, dále jsou připravovány rozsáhlejší kvantitativní výzkumy programu a komparativní česko-slovenská studie rozdílů ve fungování programu.

Evaluace vyhodnocuje předpokládané výstupy programu na úrovni znalostí, dovedností, postojů a chování žáků, současně se evaluace zaměřuje i na jeho vliv na školní klima. Předpokladem je, že s výsledky evaluace budou jeho koordinátoři v České republice 
schopni dále zvýšit jeho efektivitu, prípadné měřitelné výsledky bude možné využít i pro prezentaci programu.

Evaluace proběhla ve spolupráci Sdružení TEREZA a Technické univerzity $v$ Liberci. Předkládaný článek je zkrácenou prezentací metodiky a výsledků výzkumu, upravenou pro publikaci v odborném časopise.

\section{Východiska výzkumu}

Program Ekoškola nebyl dosud v České republice systematicky evaluován. Zpětná vazba o efektivitě programu byla zatím vytvářena spiše na základě epizodických pozorování, reflexí školních koordinátorů či hodnocení škol z pohledu auditorů z koordinujících středisek.

Epizodický charakter má i většina zahraničních evaluací programu. Např́klad v publikovaném evaluačním materiálu jihoafrického koordinátora Ekoškoly jsou informace o problémech s propojením programu se školním kurikulem, potřebě průběžné motivace školních koordinátorů návštěvou pracovníků koordinujících středisek a podpory ze strany oficiálních úřadů, či o problémech $s$ učebnicemi a další praktické zkušenosti (WESSA, 2008).

Rozsáhlý výzkum programu byl $\vee$ posledních osmi letech realizován $\vee$ jednotlivých částech Velké Británie.

Pro prezentovanou práci byla hlavní inspirací evaluace programu, která $v$ letech 2000-2001 proběhla v Irsku (O' Mahony \& Fitzgerald, 2001). V průzkumu byly srovnávány školy, které se teprve nedávno zapojily do projektu, školy $v$ projektu dlouhodobě působící a školy, které získaly ocenění - zelenou vlajku. Průzkum se skládal ze dvou oddělených částí.

V první části průzkum srovnával produkci odpadů na jednotlivých skupinách škol. Údaje byly získány $z$ celkem 47 škol $s$ více než pěti tisíci žáky. Průzkum přesvědčivě ukázal, že nejméně odpadů produkují oceněné školy a nejvíce školy, které se čerstvě zapojily do projektu. Rozdíl mezi nejlepší a nejhorší skupinou tvořil až 45 procent produkce odpadu na hlavu.

Ve druhé části průzkum srovnával environmentální postoje, znalosti a jednání žáků. Do této části průzkumu bylo zapojeno 17 škol, které získaly Zelenou vlajku a 19 škol ze stejných lokalit nezapojených do programu Ekoškola. V každé skupině bylo 654 žáků ve věku 10-13 let, průzkum proběhl $v$ roce 2001 . Ve znalostním testu bodovaly obě skupiny přibližně stejně. Rozdíly se projevily $v$ míre proenvironmentálního chování. Děti z programu Ekoškola méně často zahazují odpady a významně častěji se účastní místních environmentálních projektů, o něco častěji deklarují šetření vodou, energií a nakupování environmentálně šetrných výrobků. Častěji také diskutují o otázkách životního prostředí a tř́́dí doma odpad. Zhruba o pět procent více žáků odmítá tvrzení, že nemohou nic dělat se stavem životního prostředí.

Hlavními výstupy evaluace byla následující zjištění:

- Program má pozitivní dopady na ekologickou stopu škol;

- Žáci z déle zapojených škol mají vyšší míru víry ve vlastní možnosti (internal locus of control ${ }^{1}$ );

\footnotetext{
${ }^{1}$ Jako "locus of control" se $v$ psychologii označuje přesvědčení jedince o tom, zda události, které se mu dějí, jsou především výsledkem jeho vlastního úsilí (interní vlivy) nebo nekontrolovatelných vlivů zvenčí (externí). Locus of control zde překládáme jako "víra ve vlastní možnosti" a je vztažen k víře
} 
- Žáci z déle zapojených škol mají častější výskyt proenvironmentálního chování v oblasti ekomanagementu²;

- Žáci z déle zapojených škol hrají častěji roli názorového vůdce $v$ otázkách životního prostředí;

- Nebyl naměřen vliv programu na znalosti environmentálních problémů.

V letech 2005-2006 proběhl výzkum programu také na skotských školách (Pirrie, Elliot, McConnell \& Wilkinson, 2006). Výzkum byl zaměřen především na školní koordinátory programu a zkoumal jejich vstupní očekávání a hodnocení programu. Většina učitelů vstoupila do programu s očekáváním, že jim pomůže rozvinout školní program výchovy $\mathrm{k}$ aktivnímu občanství a že přinese škole užitek $z$ efektivnějšího využívání zdrojů. $\checkmark$ hodnocení většina respondentů uvedla, že program zvýšil status školy v místní komunitě a pomohl přehodnotit školní politiku $v$ oblasti managementu přírodních zdrojů. Silný pozitivní vliv má program podle hodnocení respondentů také na kurikulum základních škol. $\checkmark$ hodnocení měl program nejsilnější dopad na životní prostředí škol, podporu zdravého životního stylu a odhodlanost dětí zapojit se do aktivit.

\section{Metodika evaluace}

\section{Východiska použité metodiky}

Evaluaci můžeme chápat jako proces prověřování programu, zahrnující sběr a analýzu informací o aktivitách programu, jeho charakteristikách a výstupech (Patton, podle Barch, Duvall, Higgs, Wolske \& Zint, 2007). Předmětem evaluace tedy může být např́klad otázka finanční úspornosti programu, hodnocení počtu provedených aktivit, vyhodnocení míry dosažení existujících standardủ, samostatná analýza výstupư programu či další aspekty.

Pro evaluaci programu se používá specifická metodika, která zejména $v$ oblasti hodnocení výstupů programu uplatňuje metody aplikovaného pedagogického výzkumu. Výsledky pak jsou využívány nejen pro potřebu realizátorů programu, ale i pro rozvoj teorie environmentální výchovy a jsou publikovány $v$ odborných časopisech oboru (zejména Journal of Environmental Education).

Evaluace programu se zpravidla skládá ze čtyř základních fází. V první fázi upřesňujeme zadání evaluace a shrnujeme informace o programu a jeho předpokládaném fungování do tzv. logického modelu programu. V logickém modelu definujeme vstupy (zejména použité zdroje $v$ prípadě analýzy finanční úspornosti programu), produkty (zejména předpokládané aktivity programu a očekávaná míra spokojenosti účastníkú s programem) a výstupy. Těmi jsou očekávané dopady programu na rovině učení (změny či dosažení určité úrovně znalostí, dovedností a postojů), chování (resp. transferu učení do chování absolventů programu) a dopadů (reálných změn v životním prostředí či komunitě vyvolaných programem).

jednotlivce ve vlastní možnosti ovlivňovat svým rozhodováním životní prostředí vs. víře v převažující vliv externích faktorů (podle Wikipedia, http://en.wikipedia.org/wiki/Locus_of_control).

2 Jako ekomanagement se zde označují aktivity, při kterých je př́mo ovlivňováno životní prostředí s cílem prevence nebo řešení environmentálních problémů. Příkladem mưže být sázení stromů či třídění odpadů. Dalšími typy proenvironmentálního chování jsou spotřebitelské jednání, přesvědčování, politické akce a právní akce. 
Ve druhé fázi vycházíme z logického modelu a na jeho základě formulujeme evaluační otázky vymezující zkoumané oblasti programu a příslušné indikátory - konkrétní ukazatele, na základě kterých budou evaluační otázky zodpovězeny. Ve třetí fázi promýšlíme metody sběru dat a jejich zpracování. V poslední fázi pak realizujeme samotný výzkum a zpracujeme evaluační zprávu s návaznými doporučeními (Ecosystem, 2004; W.K.Kellog, 2004; Barch, Duvall, Higgs, Wolske \& Zint, 2007; Department of Environment and Conservation, 2004).

Přestože byla tato metodika sledována i v evaluaci programu Ekoškola, bylo zapotřebí provést její dílčí korekce. Evaluace měla být zaměřena na výstupy programu, ty ale nebyly přesně specifikovány a nebylo proto možné ověřovat míru jejich dosažení. Namísto ověřování očekávaných výstupư jsme proto vytvořili hypotézy o předpokládaných výstupech, které jsme dále ověřovali pomocí metod pedagogického výzkumu.

V první fázi evaluace jsme analyzovali dostupné informace o programu a jeho evaluaci v zahraničí. Na jejich základě jsme pak zformulovali evaluační otázky a naznačili vhodné indikátory. Druhým krokem bylo vyjádření předpokládaných výstupů formou hypotéz. Dále jsme již postupovali analogicky podle uvedené metodiky. Výstupem evaluace pak bylo nejenom vyhodnocení jednotlivých hypotéz a analýza silných a slabých stránek programu, ale i vytvoření logického modelu programu použitelného pro další evaluace.

Při vytváření a analýze logického modelu programu je důležité vycházet z existujících teorií o vztazích mezi jednotlivými proměnnými ovlivňujícími proenvironmentální chování. V kontextu environmentální výchovy je nejčastěji uváděn model Hungerford-Volková, rozlišující tři základní úrovně proměnných: vstupní (zejména environmentální senzitivita, $v$ menší míře pak znalosti ekologických konceptů, postoje související s ekonomikou a společností a některé další proměnné), vlastnické (zejména komplexní porozumění environmentálního problému, související $s$ relevantními výzkumnými dovednostmi a osobním zaujetím pro problém) a proměnné vlivu, ze kterých nejsilnější roli mají znalosti a dovednosti $v$ použití akčních strategií, odhodlání jednat a interní ohnisko kontroly (internal locus of control) (Hungerford \& Volk, 1990; Knapp, Volk \& Hungerford, 1997; Mony, 2002).

Některé další modely upozorňují na vliv ještě jiných proměnných. Těmi jsou např́klad situační faktory (Hines, Hungerford \& Tomera, 1986/7) či subjektivní a objektivní normy (Hammit, Freimund, Watson, Brod \& Monz, 1995).

Lze předpokládat, že program bude efektivněji ovlivňovat chování žáků, pokud se bude koncentrovat na všechny související významné proměnné. Současně můžeme pomocí některého z modelů proenvironmentálního chování interpretovat možné príčiny nízké efektivity programu ve sledovaných oblastech.

\section{Design evaluace}

Pro většinu programů je za optimální považován smíšený design evaluace kombinující kvantitativní přístup s kvalitativním (Simmons, 2008). Evaluace programu Ekoškola vychází především z kvantitativní metodiky, ale ve dvou sledovaných oblastech (problémová úloha k vyhodnocení environmentálních akčních dovedností a analýza nejsilnějších zážitkư spojených s programem) používá kvalitativní přístupy. Evaluace má proto jako celek smíšený design.

Při upřesnění designu pro sběr dat jsme vycházeli z citovaného irského modelu (O' Mahony \& Fitzgerald, 2001). V evaluaci proto porovnáváme hodnoty naměřené u škol, které $v$ nedávné době vstoupily do programu (kontrolní skupina) se školami, které obdržely titul a zelenou vlajku (experimentální skupina):

- Experimentální skupina byla vymezena jako 100-400 žáků sedmých tříd ze škol, které ve školním roce $2007 / 8$ měly či získaly zelenou vlajku. 
- Kontrolní skupina byla vymezena jako srovnatelná množina žáků sedmých tříd ze škol, které od 1. 11. 2007 vstoupily do programu Ekoškola.

Je třeba zmínit, že uvedený design není schopen s jistotou rozlišit, zda naměřené rozdíly nemohou být způsobeny jinými faktory. $V$ rámci evaluace je nicméně předpokládáno, že nejdůležitější intervenujíći proměnnou je míra zájmu školy o environmentální problematiku. Ta je pak obsažena v přihlášení se školy do programu. Do evaluace by tedy měly být zahrnuty školy, které se o environmentální tématiku zajímají, jsou ale $v$ různých fázích programu: počáteční a finální.

\section{Formulace hypotéz}

V dalším kroku bylo formulováno sedm hypotéz ověřovaných $v$ této části evaluace programu. Každá hypotéza je chápána jako alternativní k nulové hypotéze, podle které není mezi naměřenými skupinami statisticky významný rozdíl.

H1: Respondenti z experimentální skupiny hrají častěji roli názorových vůdců $v$ tématech životního prostředí než respondenti z kontrolní skupiny.

H2: Respondenti z experimentální skupiny se chovají k životnímu prostředí šetrněji než respondenti z kontrolní skupiny.

H3: Respondenti z experimentální skupiny ve srovnání s kontrolní skupinou častěji volí efektivnější strategii k řešení problémů.

H4: Respondenti z experimentální skupiny jsou častěji přesvědčeni o svých možnostech aktivně ovlivňovat životní prostředí než respondenti z kontrolní skupiny.

H5: Respondenti z experimentální skupiny vnímají ve srovnání s respondenty z kontrolní skupiny svoji roli v rozhodování o životě školy jako více participující.

H6: Respondenti z experimentální skupiny se ve škole cítí lépe, než respondenti z kontrolní skupiny.

H7: Respondenti z experimentální skupiny mají větší znalosti z oblasti ekologicky šetrného chování, než respondenti z kontrolní skupiny.

Hypotézy H1, H2 a H4 vychází přímo z výsledků irského výzkumu. Hypotéza H3 byla zformulována s cílem ověřit existenci transferu mezi aktivitami programu rozvíjejícími akční dovednosti a vlastním odpovědným environmentální chováním. Taková hypotéza je částečně podepřena modelem faktorů ovlivňujících proenvironmentální chování podle Hungerforda a Volkové (Hungerford \& Volk, 1990; Knapp, Volk \& Hungerford, 1997; Mony, 2002).

Hypotéza H5 a H6 vychází z teorií, podle kterých participace dětí na provozu školy vede $\mathrm{k}$ posilování identity žáků se školou, zlepšování školního klimatu a vztahů mezi dětmi a vyučujícími (v. např. Frank, 2001; Henton, 1996).

Hypotéza H7 byla zformulována zdánlivě v rozporu s výsledky irského výzkumu. Ve skutečnosti se zaměřuje na jinou oblast znalostí. Zatímco O' Mahony a Fitzgerald (2001) se zaměřovali na znalosti environmentálních problémů, zaměřuje se hypotéza na znalost environmentálních akčních strategií. To je $\mathrm{v}$ souladu $\mathrm{s}$ modelem faktorů podporujících environmentální odpovědné chování (Knapp, Volk \& Hungerford, 1997; Mony, 2002; Emmons, 2007). 


\section{Výběr vzorku}

V rámci výzkumu byly porovnávány skupiny žáků sedmých tříd ze škol, které teprve nedávno vstoupily do programu (kontrolní skupina) s žáky sedmých tříd škol, které získaly zelenou vlajku (experimentální skupina). Kritériím pro kontrolní skupinu (vstup do programu od 1. 11. 2007, sedmá trrída ZŠ) vyhovovalo patnáct škol, které byly osloveny s žádostí o spolupráci na výzkumu. Šest škol nereagovalo na vstupní oslovení a bylo proto z výzkumu vyřazeno. Souhlas poskytlo devět škol, data $v$ zadaném termínu zaslalo šest $z$ nich. $Z$ celkové populace se tedy podařilo získat data od 40 procent škol.

Kritériem pro experimentální skupinu bylo, aby škola $v$ roce 2008 držela nebo obhajovala zelenou vlajku a měla sedmou třídu ZŠ. Ze dvanácti škol jich reagovalo šest, data se podařilo získat od pěti škol se zelenou vlajkou. Celkem se tedy podařilo získat data od 41 procent škol. O výběr dat byli požádáni školní koordinátoři programu telefonátem a následným dopisem s namnoženými dotazníky. Celkem bylo získáno 139 dotazníků z experimentální skupiny a 192 z kontrolní skupiny. Počet respondentů se tedy pohyboval těsně pod doporučeným procentuálním podílem z celkové populace, který se pro množiny této velikosti pohybuje kolem 45-50\% (Barch, Duvall, Higgs; Wolske \& Zint, 2007).

Ve skotském výzkumu (Pirrie, Elliot, McConnell \& Wilkinson, 2006) byly z celkového počtu respondentů dále vybrány vzorky tak, aby skupiny byly vyvážené z hlediska geografického a procentního zastoupení programu $v$ okrese. Vzhledem k menšímu počtu respondentů by takový postup vedl k neúnosnému snížení vzorku. Přestože že program je v České republice poměrně rozšířen, je do něj ve Skotsku zapojeno přibližně desetkrát více škol (zhruba 2000 oproti přibližně 200 školám v České republice). Z tohoto důvodu byla $v$ evaluaci de facto zohledněna jediná intervenující proměnná a to ročník.

Nepředpokládali jsme, že by na výsledky měly mít větší vliv některé další proměnné, jako např́klad velikost obce či region. Pokud by program byl zaměřený na environmentální senzitivitu nebo na vztah k regionu a místní komunitě, bylo by možné předpokládat, že respondenti z menších obcí budou mít odlišné výsledky od dětí z velkých měst. Ekoškola je ale primárně zaměřená na dění uvnitř školy (alespoň ve své české implementaci). Porovnáme-li velikost obcí, ve kterých byly školy z obou skupin, zjistíme, že jsou poměrně vyrovnané. $V$ každé skupině byla jedna škola z velkoměsta (Prahy), jedna škola ze středně velkého města (Opava, resp. Havířov) a ostatní školy z malých měst a obcí (Bystřice pod Hostýnem, Dubá, Černovice, resp. Telč, Lomnice nad Lužnicí, Horšovský Týn, Kostelec na Hané).

Proměnná, která by měla být zahrnuta do navazujících výzkumů, je velikost školy. Školy v experimentální skupině měly v průměru 356 žáků $(S D=153)$, v kontrolní 385,5 žáka $(S D=203)$. Příčinou vyšší směrodatné odchylky v kontrolní skupině je malotřídní škola s pouhými 26 žáky, z nich ale pouze pět bylo respondenty výzkumu. S touto výjimkou se počet žáků $v$ obou skupinách pohyboval mezi 220 a 600 . Přestože tedy skupiny nejsou zcela vyrovnané, nejsou rozdíly mezi nimi tak veliké, abychom mohli očekávat větší zkreslení výsledků.

Dalšími případnými proměnnými by mohl být například prospěch žáků, kvalifikace koordinátora programu (např. absolvování specializačního studia pro koordinátory EVVO) či další faktory. Analýza takových proměnných by přesáhla finanční možnosti evaluace, mưže být ale součástí navazujících studií. Přestože v sociologických výzkumech je analýza více pozad'ových faktorů důležitá, evaluace programů environmentální výchovy často pokrývají menší počet vybraných proměnných. Kromě finančních důvodů bývá příčinou i omezenost základní množiny a nemožnost výběru z velkého počtu respondentů. $V$ neposlední řadě evaluace zpravidla vycházejí z potřeb zadavatele, pro kterého některé potenciálně měřitelné informace nemusí být pertinentní.

V každém případě je třeba uvést, že zkoumaný vzorek není zcela reprezentativní a výsledky evaluace proto mohou být zkreslené. 


\section{Metody sběru a zpracování dat}

Sběr dat byl proveden $v$ průběhu června 2008. Sběr dat zajistili koordinátoři programu z jednotlivých škol. Ti obdrželi dotazníky s pokyny pro žáky a s instrukcemi pro jejich zadání, sběr a odeslání ke zpracovateli.

1. Identifikační část, určující pohlaví a věk respondenta a jeho členství v Ekotýmu.

2. Víra $v$ možnosti, dotazníková část tvořená jednou otázkou nabízející výběr z pěti možností vyjadřujících míru souhlasu či nesouhlasu.

3. Škála odpovědného environmentálního chování, tvořenou sedmi otázkami a indikující relativní četnost př́slušného chování respondenta.

4. Test názorového vưdcovství $v$ environmentální oblasti, tvořený čtyřmi otázkami s možnostmi ANO - NE - NEVÍM.

5. Test znalostí environmentálních akčních strategií tvořený čtyřmi otázkami s možnostmi ANO - NE - NEVÍM.

6. Subjektivně pocitovaná míra partnerství s pedagogy, tvořená jednou otázkou nabízející výběr z pěti možností vyjadřujících míru souhlasu či nesouhlasu.

7. Subjektivní hodnocení míry spokojenosti ve škole, tvořené jednou otázkou nabízející výběr z pěti možností vyjadřujících míru souhlasu či nesouhlasu.

8. Otevřená problémová úloha měřící environmentální akční dovednosti.

9. Otevřená otázka zjištujuící nejsilnější zážitky respondentů spojené s programem.

Při zpracování dat jsme narazili na určitý metodologický problém. Data ve většině sledovaných proměnných jsou seřazeny na škále likertovského typu a bylo by proto možné s nimi pracovat jako s intervalovými proměnnými. Současně je pravděpodobné, že mezi konotacemi jednotlivých hodnot mohli respondenti cítit nestejné sémantické vzdálenosti. Data by proto mohlo být bezpečnější klasifikovat jako pořadová. $Z$ tohoto důvodu jsme se rozhodli pro použití dvou nezávislých ověřování signifikance rozdílu, tj. pomocí kontingenční tabulky, kterou pro tento typ dat doporučuje např. Chráska (2007: 178-182) a pomocí nepárového t-testu. $V$ prípadě, že obě metody vyhodnotily míru rozdílu pod zvolenou hladinu významnosti, považujeme výsledek za statisticky významný; v případě, že pouze jedna z nich, budeme výsledek považovat za ne zcela statisticky průkazný. Předpokládáme, že pomocí tohoto postupu snížíme riziko chyby prvního typu, přestože současně zvýšíme riziko neoprávněného odmítnutí vlivu programu na sledovanou proměnnou. Tímto způsobem byla vyhodnocována víra $v$ možnosti, škála odpovědného environmentálního chování, míra partnerství s pedagogy a míra spokojenosti ve škole.

Hladina významnosti byla pro všechna porovnávání zvolena na a=0,05. Grafickou formou jsou prezentovány procentuální rozdíly mezi oběma skupinami.

Pro porovnávání četnosti hodnot $v$ testu názorového vưdcovství jsme využili 2x3 kontingenční tabulku.

V Testu environmentálních znalostí byl nejprve vyhodnocen bodový zisk studenta pro každou otázku. Za každou správnou odpověd’ respondent získal bod, za špatnou bod 
ztratil a za volbu "nevím" nezískal ani neztratil. Pokud respondent neodpověděl na některou otázku vůbec, byl z hodnocení vyřazen. Ve druhé fázi jsme spočítali průměrné hodnoty bodových zisků studentů z obou skupin na každou otázku. Aritmetické průměry jsme pak porovnali Mann-Whitneyho testem ${ }^{3}$, hladina významnosti opět $a=0,05$.

Úloha měřící environmentální akční dovednosti předpokládala rozložit postup řešení problémů do kroků odpovídajících postupu, který se studenti učí $v$ rámci programu Ekoškola. Optimální postup tedy byl nejprve analyzovat problém a vyhodnotit, kde se v domácnosti spotřebovává nejvíce energie a kde jsou největší případné ztráty. Ve druhé fázi řešení by studenti měli navrhnout plán dalšího postupu, založený na studiu možných alternativ. Třetí fáze je implementační a monitorovací. Pokud studenti uvedli všechny tři fáze řešení problému, získali tři body. Pokud jen dvě z nich, dva body, za návrhy odpovídající jediné fázi (např. návrh řešení) jediný bod. Nerelevantní návrhy či komentáře byly hodnoceny nula body.

Průměrné bodové zisky studentů z obou skupin byly porovnány Wilcoxonovým testem pro dvě nezávislé skupiny.

Odpovědi z otevřené otázky byly kategorizovány. Ke každému výroku byl přidělen kód, související kódy byly zařazeny pod společnou kategorii. Protože získané výroky byly velmi krátké a design této části evaluace převážně kvantitativní, chápeme tuto část evaluace jako doplňkovou a otevírající otázky pro navazující kvalitativní část evaluace.

U vybraných částí evaluace jsme porovnání obou základních skupin doplnili srovnáním členů Ekotýmu s ostatními žáky v rámci experimentální skupiny.

U otázek 4-20 jsme provedli srovnání výsledků mezi chlapci a dívkami v rámci experimentální skupiny. Srovnávali jsme četnost jednotlivých odpovědí pomocí 2x5, resp. $2 \times 3$ kontingenční tabulky. Protože ani $v$ jednom př́padě nebyl naměřen statisticky významný rozdíl, nebudeme tuto skutečnost při prezentaci jednotlivých odpovědí dále uvádět.

\section{Prezentace výsledků}

\section{Charakteristika vzorku}

Experimentální skupinu tvořilo celkem 139 žáků sedmých tříd základních škol v České republice, které $v$ době výzkumu držely titul Ekoškola. Celkem byla získána data z pěti škol. Ve skupině bylo 58 chlapců a 81 dívek. Průměrný věk byl 13 let. Členy Ekotýmu bylo 32 žáků, tj. 23\% členů skupiny.

Kontrolní skupinu tvořilo celkem 192 žáků sedmých tříd základních škol, které v době od 1. 11. 2007 zahájily program. Celkem byla získána data z šesti škol. Ve skupině bylo 104 chlapců a 88 dívek, průměrný věk 13 let. Členy Ekotýmu bylo 23 žáků, tj. $11,97 \%$ členů skupiny.

37 žáků z kontrolní skupiny nedokázalo odpovědět na otázku, zda jsou členy Ekotýmu, někteří s komentářem „nevím, co to je". V experimentální skupině se nedokázal rozhodnout pouze jediný respondent.

\footnotetext{
${ }^{3}$ Chráska (2007:37) v zásadě řadí měření úrovní vědomostí didaktickým testem do intervalového typu měření. Vzhledem $\mathrm{k}$ malému rozsahu možností $v$ Testu environmentálních znalostí a $v$ zásadě kvalitativní analýze odpovědí $v$ problémové úloze jsme se raději rozhodli pro ordinální typ měření a použití Mann-Whitneyho a Wilcoxonova testu.
} 
Nerozhodnost značného počtu respondentů z kontrolní skupiny v otázce zjištující jejich členství v Ekotýmu ukazuje, že $v$ některých školách ještě program reálně nezačal nebo se nedostal do obecného povědomí. Vytvoření Ekotýmu je prvním krokem metodiky Ekoškoly. Rozdíl v poměru počtu studentů, kteří jsou členy Ekotýmu mezi oběma skupinami ukazuje, že zahájení programu a realizace jeho prvního kroku může být poměrně zdlouhavá a trvat školám déle než několik měsíců.

\section{Víra v možnosti}

Víra v možnosti (internal locus of control) je ve výzkumech hodnocena jako jedna z hlavních proměnných ovlivňujících odpovědné environmentální chování. V evaluaci odpovídala hypotéze H4:

H4: Respondenti z experimentální skupiny jsou častěji přesvědčeni o svých možnostech aktivně ovlivňovat životní prostředí než respondenti z kontrolní skupiny.

Respondenti se vyjadřovali k následující otázce:

Do jaké míry souhlasíš s následujícím tvrzením:

"Moje jednání má vliv na stav životního prostředí." souhlasím

zásadně nesouhlasím - spíše nesouhlasím - nevím - spíše souhlasím - rozhodně

Na otázku odpovědělo 130 respondentů z experimentální skupiny a 185 ze skupiny kontrolní. Ostatní respondenti na otázku neodpověděli a byli proto z vyhodnocení vyřazeni.

\begin{tabular}{|l|l|l|l|l||l|l|l|l|l|l|l|}
\hline & $\mathrm{N}$ & $\begin{array}{l}\text { Zásadně } \\
\text { nesouhlasím } \\
(\%)\end{array}$ & $\begin{array}{l}\text { Spíše } \\
\text { nesouhlasím } \\
(\%)\end{array}$ & $\begin{array}{l}\text { Nevím } \\
(\%)\end{array}$ & $\begin{array}{l}\text { Spíše } \\
\text { souhlasím } \\
(\%)\end{array}$ & $\begin{array}{l}\text { Rozhodně } \\
\text { souhlasím } \\
(\%)\end{array}$ & chí & df & $\mathrm{p}$ & $\mathrm{t}$ & $\mathrm{p}$ \\
\hline Experimentální & 130 & 5,38 & 3,07 & 23,84 & 31,53 & 36,15 & 28 & 4 & 0 & 4,11 & 0 \\
\hline Kontrolní & 185 & 4,86 & 7,56 & 41,62 & 32,97 & 12,97 & 28 & \\
\hline
\end{tabular}

Pozn.: Není-li uvedeno jinak, představuje ve všech tabulkách $N=$ počet respondentů, chí $=$ hodnota chí kvadrátu pro $2 \times 5$ kontingenční tabulku, df= degree of freedom - počet stupňư volnosti, $p=$ pravděpodobnost nesprávného odmítnutí nulové hypotézy (náhodného rozložení hodnot) při $a=0,05, t=h o d n o t a ~ n e p a ́ r o v e ́ h o ~ t-t e s t u$, $\mathbf{p}=$ pravděpodobnost nesprávného odmítnutí nulové hypotézy podle t-testu.

Z výsledků je patrný rozdíl mezi respondenty, kteří jsou rozhodně přesvědčeni o své víře $v$ možnosti ovlivňovat stav životního prostředí vs. poměr nerozhodnutých respondentů. Tento rozdíl je statisticky významný. Můžeme proto odmítnout nulovou hypotézu ve prospěch hypotézy alternativní.

Výzkum potvrdil v této oblasti výsledky irské evaluace programu (O' Mahony \& Fitzgerald, 2001). Program s vysokou pravděpodobností ovlivňuje postoje účastníků směrem k přesvědčení o reálnosti vlastních možností ovlivňovat stav životního prostředí.

Výsledky nicméně nevypovídají o tom, jak žáci své možnosti skutečně interpretují. Bylo by dobré se na tuto otázku zaměřit v rámci navazujícího kvalitativního výzkumu programu. 


\section{Odpovědné environmentální chování}

Odpovědné environmentální chování je chápáno jako hlavní cíl environmentální výchovy. $\mathrm{V}$ rámci evaluace bylo ověřováno jako hypotéza $\mathrm{H} 2$ :

H2: Respondenti z experimentální skupiny se chovají k životnímu prostředí šetrněji než respondenti z kontrolní skupiny.

V dotazníku této hypotéze odpovídaly otázky 5-11:

Tř́díš ve škole odpad?

Účastníš se ve svém volném čase akcí na ochranu přírody a životního prostředí (úklid okolí, finanční sbírky, atd.)?

Vypínáš vodu během čištění zubư?

Vypínáš doma po ukončení práce počítač?

Když odcházíš z místnosti, zhasneš?

Piješ vodu z kohoutku?

Nosíš si do obchodu na nákup vlastní tašku nebo batoh?

$\mathrm{Na}$ všechny otázky odpovědělo 114 respondentů z experimentální skupiny a 177 z kontrolní skupiny. Žáci, kteři neodpověděli na některou z otázek, byli z vyhodnocování této části vyřazeni.

Trídíš ve škole odpad?

\begin{tabular}{|l|l|l|l|l|l|l|l|l|l|l|}
\hline & N & $\begin{array}{l}\text { Nikdy či } \\
\text { zř́dka } \\
(\%)\end{array}$ & $\begin{array}{l}\text { Občas } \\
(\%)\end{array}$ & $\begin{array}{l}\text { Často } \\
(\%)\end{array}$ & $\begin{array}{l}\text { Pokaždé } \\
(\%)\end{array}$ & chí & df & p & t & p \\
\hline Experimentální & 114 & 2,63 & 19,29 & 29,82 & 48,24 & 64 & 4 & 0 & 8,78 & 0,0001 \\
\hline Kontrolní & 177 & 24,85 & 40,11 & 22,03 & 12,99 & 6 & 4 & \\
\hline
\end{tabular}

Pozn. Pro potřeby kontingenční tabulky byly z dưvodu velmi malých hodnot $v$ experimentální skupině sloučeny hodnoty "Nikdy" a "Zřídka". Použita byla proto $2 \times 4$ kontingenční tabulka.

Žáci z experimentální skupiny statisticky významně častěji tř́íí odpad, než žáci z kontrolní skupiny. Nejvýraznější rozdíly jsou mezi žáky, kteří trídí odpad pokaždé a jen občas.

Účastníš se ve svém volném čase akcí na ochranu přírody a životního prostředí (úklid okolí, finanční sbírky, atd.)?

\begin{tabular}{|l|l|l|l|l|l|l|l|l|l|l|l|}
\hline & N & $\begin{array}{l}\text { Nikdy } \\
(\%)\end{array}$ & $\begin{array}{l}\text { Zř́dka } \\
(\%)\end{array}$ & $\begin{array}{l}\text { Občas } \\
(\%)\end{array}$ & $\begin{array}{l}\text { Často } \\
(\%)\end{array}$ & $\begin{array}{l}\text { Pokaždé } \\
(\%)\end{array}$ & chí & df & p & p \\
\hline Experimentální & 114 & 23,68 & 19,29 & 42,1 & 11,4 & 3,5 & 45,2 & 4 & 0 & 6,21 & 0,0001 \\
\hline Kontrolní & 177 & 57,06 & 22,03 & 14,12 & 3,95 & 2,82 & 45 & \\
\hline
\end{tabular}


Přestože pokaždé, když je př́ležitost se akcí účastní mizivé procento studentů z obou skupin, je zřejmý rozdíl mezi procentem žáků, kteří se neúčastní nikdy a kteří se účastní občas. Rozdíly jsou opět statisticky významné.

Vypínáš vodu během čištění zubů?

\begin{tabular}{|l|l|l|l|l|l|l|l|l|l|l|l|}
\hline & $\mathrm{N}$ & $\begin{array}{l}\text { Nikdy } \\
(\%)\end{array}$ & $\begin{array}{l}\text { Ž̌́dka } \\
(\%)\end{array}$ & $\begin{array}{l}\text { Občas } \\
(\%)\end{array}$ & $\begin{array}{l}\text { Často } \\
(\%)\end{array}$ & $\begin{array}{l}\text { Pokaždé } \\
(\%)\end{array}$ & chí & df & p & t & p \\
\hline Experimentální & 114 & 7,01 & 10,52 & 21,92 & 4,38 & 56,14 & 26,5 & 4 & 0 & 5,1 & 0,0001 \\
\hline Kontrolní & 177 & 22,59 & 14,68 & 27,68 & 6,77 & 28,24 & & \\
\hline
\end{tabular}

Rozdíl mezi respondenty, kteří vypínají vodu pokaždé, resp. nikdy, je opět jasně viditelný. I tyto rozdíly jsou statisticky významné.

Vypínáš doma po ukončení práce počítač?

\begin{tabular}{|l|l|l|l|l|l|l|l|l|l|l|l|}
\hline & $\mathrm{N}$ & $\begin{array}{l}\text { Nikdy } \\
(\%)\end{array}$ & $\begin{array}{l}\text { Žŕdka } \\
(\%)\end{array}$ & $\begin{array}{l}\text { Občas } \\
(\%)\end{array}$ & $\begin{array}{l}\text { Často } \\
(\%)\end{array}$ & $\begin{array}{l}\text { Pokaždé } \\
(\%)\end{array}$ & chí & df & $\mathrm{p}$ & $\mathrm{t}$ & $\mathbf{p}$ \\
\hline Experimentální & 114 & 10,52 & 8,77 & 19,29 & 13,15 & 48,24 & 8 & 4 & 0,069 & 2,69 & 0,007 \\
\hline Kontrolní & 177 & 21,46 & 12,42 & 15,81 & 14,12 & 36,15 & 8,69 & 4 & 0,007 \\
\hline
\end{tabular}

U této otázky se objevil rozdíl ve vyhodnocení výsledků podle kontingenční tabulky (při chápání proměnné jako pořadové) a podle t-testu (při chápání proměnné jako intervalové). Statistickou významnost rozdílu mezi skupinami proto nepovažujeme za zcela prokázanou.

Když odcházíš z místnosti, zhasneš?

\begin{tabular}{|l|l|l|l|l|l|l|l|l|l|l|l|}
\hline & $\mathrm{N}$ & $\begin{array}{l}\text { Nikdy } \\
(\%)\end{array}$ & $\begin{array}{l}\text { Zř́dka } \\
(\%)\end{array}$ & $\begin{array}{l}\text { Občas } \\
(\%)\end{array}$ & $\begin{array}{l}\text { Často } \\
(\%)\end{array}$ & $\begin{array}{l}\text { Pokaždé } \\
(\%)\end{array}$ & chí & df & $\mathrm{p}$ & $\mathrm{t}$ & $\mathrm{P}$ \\
\hline Experimentální & 114 & 2,63 & 1,75 & 15,78 & 30,7 & 49,12 & 6,28 & 4 & 0,18 & 1,91 & 0,058 \\
\hline Kontrolní & 177 & 4,51 & 7,9 & 16,94 & 27,11 & 43,5 & 6,2 & & \\
\hline
\end{tabular}

Naměřené rozdíly nejsou statisticky významné.

Piješ vodu z kohoutku?

\begin{tabular}{|l||l|l|l|l|l|l|l|l|l|l|l|}
\hline & $\mathrm{N}$ & $\begin{array}{l}\text { Nikdy } \\
(\%)\end{array}$ & $\begin{array}{l}\text { Zř́dka } \\
(\%)\end{array}$ & $\begin{array}{l}\text { Občas } \\
(\%)\end{array}$ & $\begin{array}{l}\text { Často } \\
(\%)\end{array}$ & $\begin{array}{l}\text { Pokaždé } \\
(\%)\end{array}$ & chí & df & p & t & p \\
\hline Experimentální & 114 & 12,28 & 19,29 & 24,56 & 30,7 & 13,15 & 7,3 & 4 & 0,121 & 2,29 & 0,023 \\
\hline Kontrolní & 177 & 19,77 & 18,64 & 30,5 & 24,29 & 6,77 & 7,3 & \\
\hline
\end{tabular}


Pomocí t-testu jsme na rozdíl od kontingenční tabulky našli statistickou významnost rozdílu mezi výsledky obou skupin. Vzhledem k rozdílům $v$ testování ale nepovažujeme tuto skutečnost za dostatečně potvrzenou.

Nosíš si do obchodu na nákup vlastní tašku nebo batoh?

\begin{tabular}{|l|l|l|l|l|l|l|l|l|l|l|l|}
\hline & $\mathrm{N}$ & $\begin{array}{l}\text { Nikdy } \\
(\%)\end{array}$ & $\begin{array}{l}\text { Zř́dka } \\
(\%)\end{array}$ & $\begin{array}{l}\text { Občas } \\
(\%)\end{array}$ & $\begin{array}{l}\text { Často } \\
(\%)\end{array}$ & $\begin{array}{l}\text { Pokaždé } \\
(\%)\end{array}$ & chí & df & $\mathrm{p}$ & $\mathrm{t}$ & $\mathbf{p}$ \\
\hline Experimentální & 114 & 7,89 & 4,38 & 11,4 & 30,7 & 45,61 & 13,3 & 4 & 0,01 & 2,98 & 0,003 \\
\hline Kontrolní & 177 & 9,6 & 11,86 & 21,46 & 26,55 & 30,5 & 13,5 & \\
\hline
\end{tabular}

Naměřené rozdíly jsou tentokrát statisticky významné. Dobře viditelný je rozdíl v poměru respondentů, kteří si pokaždé nosí vlastní tašku.

Respondenti z experimentální skupiny deklarovali ve čtyřech ze sedmi otázek vyšší stupeň odpovědného environmentálního chování, ve dvou dalších případech nebyla vyšší míra proenvironmentálního chování respondentů z experimentální skupiny zcela průkazná a pouze $v$ jednom nebyly rozdíly mezi skupinami statisticky významné. Nulovou hypotézu je proto možné odmítnout a přijmout hypotézu alternativní.

Program Ekoškola pravděpodobně ovlivňuje proenvironmentální chování žáků v oblasti ekomanagementu.

Na základě provedené evaluace nelze s určitostí říct, zda některá z témat Ekoškoly fungují lépe, než jiná. Ze čtyř témat programu nicméně byly relativně horší výsledky naměřeny u otázek odpovídajících tématu Energie. Je možné, že tato část kurikula není dosud dobře zpracována a že vyžaduje revize. Jiným vysvětlením může být také vliv jiných proměnných - např. snaha o ekonomické chování v rodině.

\section{Názorové vưdcovství}

Názorové vůdcovství koresponduje s přesvědčovacími schopnostmi jako s jednou z akčních dovedností v občanské oblasti. V průzkumu figuruje pod hypotézou H1.

H1: Respondenti z experimentální skupiny hrají častěji roli názorových vưdců v tématech životního prostředí než respondenti z kontrolní skupiny.

Ověřována byla prostřednictvím otázek 12 a 13, z nichž každá měla dva podbody:

Bavil ses s někým za poslední měsíc o životním prostředí?

Doma: ANO - NE - NEVÍM

S kamarády: ANO - NE - NEVÍM

Snažil ses za poslední měsíc někoho přesvědčit, aby se choval šetrněji $k$ životnímu prostředí?

Doma: ANO - NE - NEVÍM

S kamarády: ANO - NE - NEVÍM

Na otázky odpovědělo 125 členů experimentální a 160 členů kontrolní skupiny. Ostatní odpovědi nebyly úplné a byly proto z této části vyřazeny. 
Bavil ses s někým za poslední měsíc o životním prostředí? / Doma

\begin{tabular}{|l|l|l|l|l|l||l|l|}
\hline & $\mathrm{N}$ & $\begin{array}{l}\text { Ano } \\
(\%)\end{array}$ & $\begin{array}{l}\text { Ne } \\
(\%)\end{array}$ & $\begin{array}{l}\text { Nevím } \\
(\%)\end{array}$ & chí & df & $\mathrm{p}$ \\
\hline Experimentálnín & 125 & 39,2 & 49,6 & 11,2 & 11,9 & 2 & 0,003 \\
\hline Kontrolní & 160 & 20,62 & 63,12 & 16,25 & & \\
\hline
\end{tabular}

Naměřené rozdíly mezi skupinami jsou statisticky významné ve prospěch experimentální skupiny.

Bavil ses s někým za poslední měsíc o životním prostředí? / S kamarády

\begin{tabular}{|l|l|l|l|l|l|l|l|}
\hline & $\mathrm{N}$ & $\begin{array}{l}\text { Ano } \\
(\%)\end{array}$ & $\begin{array}{l}\mathrm{Ne} \\
(\%)\end{array}$ & $\begin{array}{l}\text { Nevím } \\
(\%)\end{array}$ & chí & df & $\mathrm{p}$ \\
\hline Experimentální & 125 & 39,2 & 46,4 & 14,4 & 29 & 2 & 0 \\
\hline Kontrolní & 160 & 13,12 & 75 & 11,87 & 29 \\
\hline
\end{tabular}

Naměřené rozdíly mezi skupinami jsou statisticky významné, opět ve prospěch experimentální skupiny.

Snažil ses za poslední měsíc někoho přesvědčit, aby se choval šetrněji k životnímu prostředí?/ Doma

\begin{tabular}{|l|l|l|l|l|l|l|l|}
\hline & $\mathrm{N}$ & $\begin{array}{l}\text { Ano } \\
(\%)\end{array}$ & $\begin{array}{l}\text { Ne } \\
(\%)\end{array}$ & $\begin{array}{l}\text { Nevím } \\
(\%)\end{array}$ & chí & df & p \\
\hline Experimentální & 125 & 43,2 & 46,4 & 10,4 & 29,8 & 2 & 0 \\
\hline Kontrolní & 160 & 14,37 & 72,5 & 13,12 & 29 & \\
\hline
\end{tabular}

Velmi přesvědčivý a statisticky významný rozdíl mezi oběma skupinami.

Snažil ses za poslední měsíc někoho přesvědčit, aby se choval šetrněji k životnímu prostředí?/ S kamarády

\begin{tabular}{|l|l|l|l|l|l|l|l|}
\hline & $\mathrm{N}$ & $\begin{array}{l}\text { Ano } \\
(\%)\end{array}$ & $\begin{array}{l}\text { Ne } \\
(\%)\end{array}$ & $\begin{array}{l}\text { Nevím } \\
(\%)\end{array}$ & chí & df & p \\
\hline Experimentální & 125 & 27,2 & 54,4 & 18,4 & 15,2 & 2 & 0 \\
\hline Kontrolní & 160 & 11,87 & 75,62 & 12,5 & & \\
\hline
\end{tabular}

I $\vee$ poslední otázce byl naměřen statisticky významný rozdíl ve prospěch experimentální skupiny. 
Ve všech otázkách se objevily statisticky významné rozdíly ve prospěch experimentální skupiny. Účastníci programu Ekoškola významně častěji diskutují o problémech životního prostředí s kamarády i doma.

Nulovou hypotézu je proto třeba odmítnout ve prospěch hypotézy alternativní.

\section{Test znalostí environmentálních akčních strategií}

Znalosti environmentálních akčních strategií jsou další klíčovou komponentou odpovědného environmentálního chování. V rámci evaluace byla ověřována hypotéza H7.

H7: Respondenti z experimentální skupiny mají větší znalosti z oblasti ekologicky šetrného chování, než respondenti z kontrolní skupiny.

Hypotéza byla ověřována pomocí vědomostního testu v otázkách 14-17. Dále jsou prezentovány průměrné bodové zisky obou skupin pro každou otázku. Do hodnocení bylo zařazeno 133 členů experimentální a 182 členů kontrolní skupiny. Ostatní respondenti neodpověděli na jednu či více otázek a byli proto $z$ hodnocení testu vyřazeni.

Otázka č. 14: Nejvíc vody se v běžné domácnosti spotřebuje při praní. Je to pravda?

ANO / NE / NEVÍM (správná odpověd’ NE).

Otázka č. 15: Nápoje $v$ plechovce jsou z hlediska životního prostředí šetrnější, než v PET láhvi. Je to pravda?

ANO / NE / NEVÍM (správná odpověd' NE).

Otázka č. 16: Na často sekaných zahradách typu "anglický trávník" najdeme méně rostlinných a živočišných druhů, než na nepravidelně udržovaných pozemcích. Je to pravda?

ANO / NE / NEVÍM (správná odpověd'ANO).

Otázka č. 17: Z hlediska spotřeby energie je lepší si vodu na špagety uvařit $\checkmark$ rychlovarné konvici, než na plotýnce elektrického sporáku. Je to pravda?

ANO / NE / NEVÍM (správná odpověd' ANO).

Obr. č. 1: Test znalosti akčních strategií

Test znalosti akčnich strategii (prủmẽrné zisky)

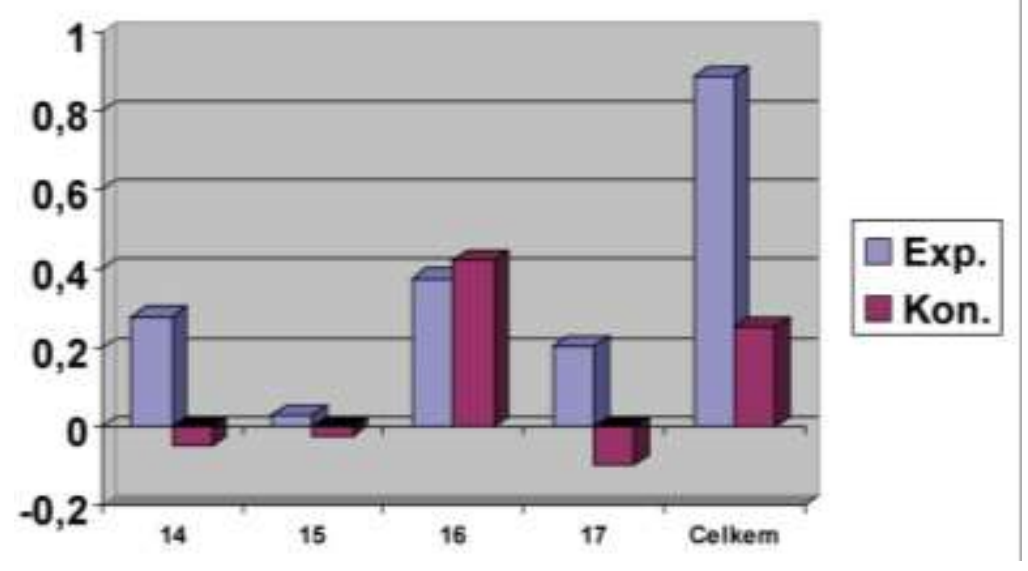




\begin{tabular}{|l|l|l|l|l|l|l|l|l|l|}
\hline Ot. č. & $\begin{array}{l}\text { Experim. } \\
\text { (průměr) }\end{array}$ & $\mathrm{SD}$ & $\begin{array}{l}\text { Kontrolní } \\
\text { (průměr) }\end{array}$ & $\mathrm{SD}$ & $\mathrm{SD}$ & $\mathrm{U}$ & $\mathrm{z}$ & $\mathrm{p} 1$ & $\mathrm{p} 2$ \\
\hline 14 & 0,278 & 0,81 & $-0,049$ & 0,76 & 0,782 & 9327 & 3,48 & 0,0003 & 0,0005 \\
\hline 15 & 0,03 & 0,807 & $-0,021$ & 0,765 & 0,783 & 11665 & 0,55 & 0,2912 & 0,5823 \\
\hline 16 & 0,376 & 0,745 & 0,423 & 0,658 & 0,696 & 12290 & $-0,23$ & 0,409 & 0,81 \\
\hline 17 & 0,203 & 0,814 & $-0,098$ & 0,737 & 0,77 & 9542 & 3,21 & 0,0007 & 0,0013 \\
\hline Celkem & $\mathbf{0 , 8 8 7}$ & $\mathbf{1 , 5 2}$ & $\mathbf{0 , 2 5 3}$ & $\mathbf{1 , 4 4}$ & $\mathbf{1 , 4 7}$ & $\mathbf{9 0 9 4}$ & $\mathbf{3 , 7 7}$ & $\mathbf{0 , 0 0 0 1}$ & $\mathbf{0 , 0 0 0 2}$ \\
\hline $\mathrm{N}$ & 133 & & 182 & & & & & & \\
\hline
\end{tabular}

Pozn.: SD=standard deviation, směrodatná odchylka; U=hodnota Mann-Whitneyho testu, p1 a p2 - pravděpodobnosti náhodného vzniku rozdílư mezi skupinami ( $p 1$ pro menší skupiny, p2 pro větší skupiny).

$\checkmark$ úspěšnosti mezi oběma skupinami existují statisticky významné rozdíly ve prospěch experimentální skupiny. Členové experimentální skupiny statisticky významně lépe odpovídali na otázky č. 14 a 17. Rozdíly v úspěšnosti odpovědí na otázky č. 15 a 16 nejsou statisticky významné.

Pro srovnání jsme $v$ rámci experimentální skupiny analyzovali rozdíly mezi členy Ekotýmu a ostatními studenty:

\begin{tabular}{|l|l|l|l|l|l|}
\hline & N & Průměrný zisk & SD & W & p \\
\cline { 1 - 4 } Ekotým & 31 & 0,68 & 1,74 & \multirow{2}{*}{1936} & \multirow{2}{*}{0,4546} \\
\hline Nečlen & 102 & 0,95 & 1,44 & & \\
\hline
\end{tabular}

Pozn.: W=hodnota Wilcoxonova testu pro dva nezávislé vzorky, $p=$ pravděpodobnost neoprávněného odmítnutí nulové varianty.

Rozdíly mezi oběma skupinami ale nebyly statisticky významné.

Žáci z experimentální skupiny byli $v$ testu statisticky významně úspěšnější, než žáci z kontrolní skupiny. Naměřený rozdíl můžeme hodnotit jako střední efekt programu. Nulovou hypotézu proto můžeme odmítnout ve prospěch hypotézy alternativní. Program Ekoškola se značnou pravděpodobností rozvíjí u žáků znalosti akčních strategií v oblasti ekomanagementu.

Doplňující test neukázal významné rozdíly ani v rámci experimentální skupiny mezi členy Ekotýmu a ostatními studenty.

\section{Partnerství s pedagogy}

Předpokladem projektové výuky je určitá míra participačního př́stupu mezi pedagogy a žáky. Do jaké míry je takové partnerství pocitóováno účastníky Ekoškoly, je testováno v hypotéze $\mathrm{H} 5$. 
H5: Respondenti z experimentální skupiny vnímají ve srovnání s respondenty z kontrolní skupiny svoji roli v rozhodování o životě školy jako více participující.

V dotazníku bylo toto hodnocení zjištováno v otázce č. 18: partnera?

Do jaké míry si myslíš, že Tě učitelé v rozhodování o životě školy berou jako

Na otázku odpovědělo celkem 125 členů experimentální a 165 kontrolní skupiny.

\begin{tabular}{|l|l|l|l|l|l|l|l|l|l|l|l|}
\hline & N & $\begin{array}{l}\text { Nikdy } \\
(\%)\end{array}$ & $\begin{array}{l}\text { Zř́dka } \\
(\%)\end{array}$ & $\begin{array}{l}\text { Občas } \\
(\%)\end{array}$ & $\begin{array}{l}\text { Často } \\
(\%)\end{array}$ & $\begin{array}{l}\text { Pokaždé } \\
(\%)\end{array}$ & chí & df & p & t & p \\
\hline Experimentální & 125 & 23,2 & 19,2 & 36,8 & 16,8 & 4 & 5 & 4 & 0,237 & 1,9 & 0,059 \\
\hline Kontrolní & 165 & 34,54 & 18,78 & 31,51 & 10,9 & 4,24 & 5,53 & 4,24 & \\
\hline
\end{tabular}

Rozdíly mezi skupinami nejsou statisticky významné, přestože t-test naměřil téměř hraniční hladinu významnosti rozdílu ve prospěch žáků Ekoškoly.

Vzhledem k charakteru programu jsme dále srovnávali, zda nejsou statisticky významné rozdíly mezi členy a nečleny Ekotýmu $v$ experimentální skupině. Do vyhodnocení bylo zařazeno 125 členů, z toho 29 bylo členy Ekotýmu a 96 nikoliv.

\begin{tabular}{|l|l|l|l|l|l|l|l|l|l|l|l|}
\hline & N & $\begin{array}{l}\text { Nikdy } \\
(\%)\end{array}$ & $\begin{array}{l}\text { Zrídka } \\
(\%)\end{array}$ & $\begin{array}{l}\text { Občas } \\
(\%)\end{array}$ & $\begin{array}{l}\text { Často } \\
(\%)\end{array}$ & $\begin{array}{l}\text { Pokaždé } \\
(\%)\end{array}$ & chí & df & p & t & p \\
\hline Ekotým & 29 & 27,58 & 3,44 & 44,82 & 17,24 & 6,89 & 6,65 & 4 & 0,36 & 0,73 & 0,48 \\
\hline Nečlen & 96 & 21,87 & 23,95 & 34,37 & 16,66 & 3,12 & 6,40 & \\
\hline
\end{tabular}

Pozn.: Pro vyhodnocování pomocí kontingenční tabulky byly sloučeny četnosti hodnot "nikdy" a "zřídka" a na současně "často" a "pokaždé." Byla proto použita 2x3 kontingenční tabulka. P udává míru pravděpodobnosti podle t-testu.

Rozdíly mezi skupinami nejsou statisticky významné.

Nulovou hypotézu se nepodařilo vyvrátit a je jí proto třeba přijmout. Na základě naměřených výsledků nelze říct, že by dlouhodobí účastníci programu Ekoškola (se zelenou vlajkou) měli s učiteli více partnerský vztah, než účastníci na začátku programu. Rozdíly nebyly naměřeny ani mezi členy Ekotýmu a ostatními studenty $v$ rámci experimentální skupiny.

Program Ekoškola pravděpodobně participaci studentů $s$ učiteli nerozvijí, nebo ji alespoň žáci nepocitují.

Vzhledem $\mathrm{k}$ subjektivnosti měřeného vyjádření by bylo velmi vhodné zaměřit se na tuto oblast v kvalitativním výzkumu a to jak ze strany učitelů, tak ze strany žáků.

\section{Spokojenost ve škole}

Je předpokladem, že ve škole, ve které se uplatňují aktivní metody výuky, se žáci cítí spokojeněji. Vyšší spokojenost by také měla souviset $s$ vyšší mírou participace na vedení školy. Předpoklad jsme formulovali do hypotézy H6.

H6: Respondenti z experimentální skupiny se ve škole cítí lépe, než respondenti z kontrolní skupiny. 
Hypotéze odpovídala otázka č. 19:

Jak se ve škole cítíš?

Velmi špatně / Spiše špatně / Ani dobře, ani špatně / Spiše dobře / Velmi dobře

Na otázku odpovědělo 125 členů experimentální a 165 kontrolní skupiny.

\begin{tabular}{|l|l|l|l|l|l|l|l|l|l|l|l|}
\hline & & $\begin{array}{l}\text { Velmi } \\
\text { špatně } \\
(\%)\end{array}$ & $\begin{array}{l}\text { Spíše } \\
\text { špatně } \\
(\%)\end{array}$ & $\begin{array}{l}\text { Ani } \\
\text { dobře, ani } \\
\text { špatně } \\
(\%)\end{array}$ & $\begin{array}{l}\text { Spíše } \\
\text { dobře } \\
(\%)\end{array}$ & $\begin{array}{l}\text { Velmi } \\
\text { dobře } \\
(\%)\end{array}$ & chí & df & $\mathrm{p}$ & $\mathrm{t}$ & p \\
\hline Experimentální & 125 & 3,2 & 7,2 & 32,8 & 41,6 & 15,2 & 4,2 & 4 & 0,38 & 0,42 & 0,67 \\
\hline Kontrolní & 165 & 7,87 & 5,45 & 35,15 & 34,54 & 16,96 & 42 & \\
\hline
\end{tabular}

Rozdíly mezi skupinami nejsou statisticky významné.

Stejně jako u předešlé otázky jsme srovnávali, zda nejsou statisticky významné rozdíly mezi členy a nečleny Ekotýmu v experimentální skupině. Do vyhodnocení bylo opět zařazeno 125 respondentů, z toho 29 bylo členy Ekotýmu a 96 nikoliv.

\begin{tabular}{|c|c|c|c|c|c|c|c|c|c|c|}
\hline & $N$ & $\begin{array}{l}\text { Velmi } \\
\text { špatně } \\
(\%)\end{array}$ & $\begin{array}{l}\text { Spíše } \\
\text { špatně } \\
(\%)\end{array}$ & $\begin{array}{l}\text { Ani } \\
\text { dobře, } \\
\text { ani } \\
\text { špatně } \\
(\%)\end{array}$ & $\begin{array}{l}\text { Spíše } \\
\text { dobře } \\
(\%)\end{array}$ & $\begin{array}{l}\text { Velmi } \\
\text { dobře } \\
(\%)\end{array}$ & W & p1 & $U$ & p2 \\
\hline Ekotým & 29 & 3,44 & 3,44 & 20,68 & 44,82 & 27,58 & \multirow{2}{*}{2190} & \multirow{2}{*}{0,03} & \multirow{2}{*}{0,03} & \multirow{2}{*}{0,03} \\
\hline Nečlen & 96 & 3,125 & 8,33 & 36,45 & 40,62 & 11,45 & & & & \\
\hline
\end{tabular}

Pozn.: Protože očekávané četnosti $v$ kontingenční tabulce zưstaly nižší než pět $i$ v prrípadě sloučení četnosti odpovědí "velmi špatně" a "spišse špatně" ve skupině Ekotým, byl místo kontingenční tabulky využit Wilcoxonův test pro dva různé výběry ( $p 1)$ a pro kontrolu Mann-Whitneyho test (p2).

Členové ekotýmu se ve škole cítí v průměru lépe, než ostatní žáci. Vzhledem $\mathrm{k}$ malé velikosti vzorku považujeme za důležité tuto oblast dále zkoumat v navazujících šetřeních.

Stejně jako $v$ minulém př́padě, ani tentokrát se nepodařilo nulovou hypotézu vyvrátit. Výzkum naznačuje, že dlouhodobá účast v programu Ekoškola neovlivňuje to, jak se žáci ve škole cítí. Rozdíly se ale ukázaly mezi členy ekotýmu a ostatními žáky zapojených škol.

I $\vee$ tomto prípadě ale doporučujeme prozkoumání této oblasti navazujícím kvalitativním výzkumem. K tématu se současně vrátíme při rozboru poslední otázky dotazníku.

\section{Environmentální akční dovednosti}

Poslední zkoumanou oblastí byly environmentální akční dovednosti žáků. Je předpokladem, že stejně jako znalosti akčních strategií $i$ akční dovednosti významně ovlivňují proenvironmentální chování. Předpoklad byl vyjádřen hypotézou H3.

H3: Respondenti z experimentální skupiny častěji volí ve srovnání s kontrolní skupinou efektivnější strategii k řešení problémů. 
V rámci dotazníku měli respondenti řešit následující úkol:

Otázka č. 20. Představ si následující situaci: Tvoji rodiče dostanou účet za elektř̌inu. Jsou nespokojení, že musí zaplatit spoustu peněz, protože jste měli velkou spotřebu. Jaký postup bys volil/-a k tomu, abyste svoji spotřebu snízili? (Odpověz prosím ve 3-6 větách.)

Na otázku odpovědělo 129 respondentů z experimentální a 161 z kontrolní skupiny.

Zvolené postupy byly bodovány na stupnici $0-3$. Počet bodů odpovídal počtu fází řešení problému, které byly do návrhu zahrnuty (1. analýza, 2. plán, 3. implementace a monitorování).

\begin{tabular}{|l|l|l|l|l|l|}
\hline & N & $\begin{array}{l}\text { Průměrný } \\
\text { zisk }\end{array}$ & SD & W & p \\
\hline Experimentální & 129 & 0,674 & 0,47 & \multirow{2}{*}{21085.5} & 0,001 \\
\hline Kontrolní & 161 & 0,453 & 0,512 & & \\
\hline
\end{tabular}

Pozn.: W=hodnota Wilcoxonova testu pro dva nezávislé výběry.

Naměřené rozdíly jsou statisticky významné.

Přestože členové experimentální skupiny získali významně vyšší průměrný zisk, nelze nulovou hypotézu odmítnout. Důvodem je, že ani jedna skupina neprokázala skutečné akční dovednosti, ale pouze různou úroveň znalostí akčních strategií.

V experimentální skupině nezískal ani jeden respondent více, než jeden bod ze tří, $\checkmark$ kontrolní skupině získal jeden student dva body. S uvedenou výjimkou žádný student nenavrhoval postup $\mathrm{k}$ řešení problému, ale pouze více ( 1 bod) či méně ( 0 bodů) realistické návrhy řešení. Zcela chyběla fáze analýzy i následného monitoringu.

Na základě vyhodnocení úkolu proto nelze říct, že program Ekoškola rozvíjí akční dovednosti žáků $v$ oblasti ekomanagementu. Vzhledem $k$ významu zjištění pro evaluaci programu by bylo vhodné se na tuto oblast dále zaměřit a prošetřit ji dalšími výzkumnými metodami, abychom eliminovali riziko zkreslení výsledků v důsledku špatného pochopení otázky.

\section{Zážitky spojované s Ekoškolou}

V této části jsme kategorizovali odpovědi na otevřenou otázku č. 21:

A tohle je poslední otázka: Když se mluví o Ekoškole, jaký nejsilnější zážitek/moment se Ti vybaví? (Odpověz prosím ve 3-6 větách.)

Obr. č.2: Analýza kategorie Procesy v experimentální skupině.

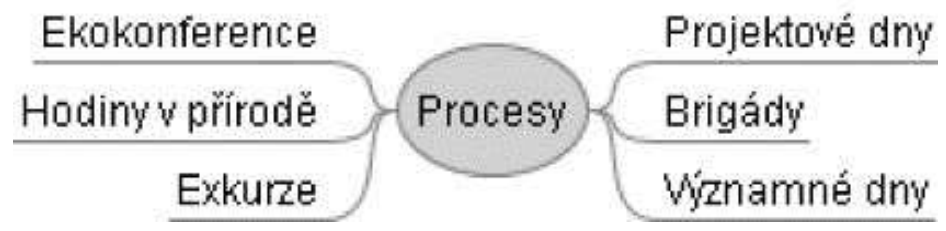

Nejčastěji zastoupenou kategorií u experimentální skupiny jsou Procesy. Studenti uváděli př́klady akcí, kdy se dělo něco mimořádného, co obohatilo běžný styl výuky. 
- jak jsme měli projektový den $v$ okolí školy. Rozeznávali jsme stromy, rostliny a zkoumali živočichy. Tohle mě opravdu bavilo

Uváděné akce se liší po jednotlivých školách. Nejčastěji byly uváděny projektové dny a ekokonference, vycházky do prírody, spojené s úkoly nebo akce spojené s významnými dny:

- já si třeba vybavím den země, Terry Fox, den bez aut, přispívat na postižené

Fakt, že nejvíce sycená kategorie se týká procesů, naznačuje, že děti program vnímají především jako obohacení běžného kurikula o nový typ aktivit. Těmi jsou jak aktivity ř́zené učitelem (exkurze, hodiny $v$ př́rodě), tak aktivity $\mathrm{s}$ dominantní úlohou žáků (ekokonference, projektové dny).

Obr. č.3: Analýza kategorie Výstupy v experimentální skupině.

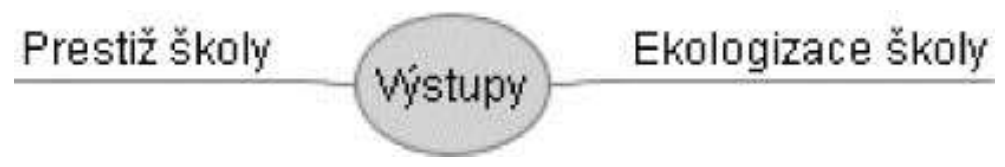

Kategorie výstupů je druhá nejčastěji uváděná v experimentální skupině. Pod ekologizaci školy se ve většině prípadů zařadilo trrídění odpadu na škole, dále šetření elektřinou, vodou, papírem, sběr žaludů a kaštanů, sběr odpadků kolem školy, úklid ve tř́ídě.

- no nejhezčí jsou ta okna, co tu máme. Také se mi líbí cedulky s nápisem "zhasni a šetři" ale nejlepší byla ekopřednáška a to jak jsou všude koše

Prestiž školy byla zmiňovaná $\mathrm{v}$ jediné škole ze vzorku; škola získala ocenění Ekoškola roku. Toto ocenění bylo zjevně žáky vnímáno jako významné:

- když jsme měli normální hodinu, myslím, že češtinu a ředitel v rozhlase oznámil, že jsme Ekoškola roku

Kategorie naznačuje, že žáci vnímají dopady, jaké program má na školu a jsou schopni cítit hrdost, pokud jsou součástí oceněné školy.

Obr. č.4: Analýza kategorie Vztahy v experimentální skupině.

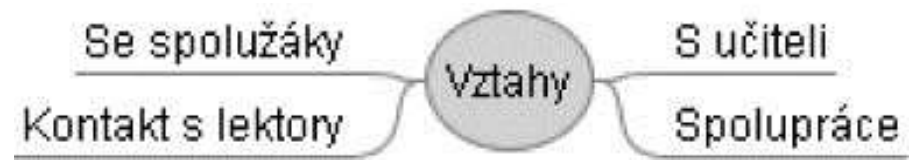

Jen sporadicky je zastoupená kategorie vztahů. Je zmíněn jeden (negativní) kontakt s učitelem, jeden (negativní) kontakt s lektory z koordinujícího střediska, jedna vzpomínka na epizodu se spolužákem a dva zážitky týkající se spolupráce v týmu. 
Malé zastoupení kategorie naznačuje, že rovina vztahů se spolužáky, učiteli či spolupráce jako taková není tím, co si studenti s programem spojují. Zajímavý je také výskyt negativních zkušeností.

21 z celkových 121 respondentů z experimentální skupiny, tj. 17,3\% si nedokázalo k programu Ekoškola vybavit nic. Tuto část studentů tedy program pravděpodobně míjí.

Podle očekávání se odpovědi členů kontrolní skupiny značně odlišovaly.

Obr. č. 5: Analýza kategorie Prekoncepty v kontrolní skupině.

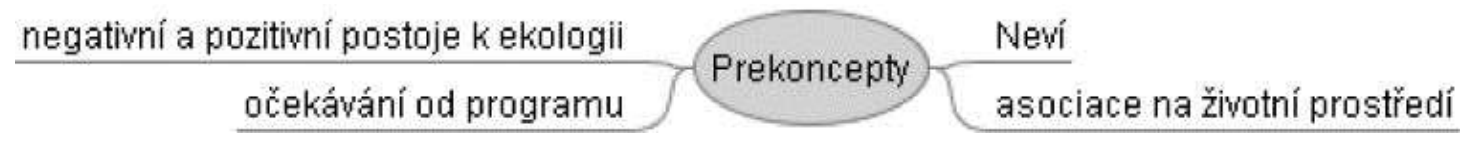

Zdaleka nejvíce byly zastoupeny odpovědi žáků, kteří si s programem nespojují nic konkrétního, resp. název programu jim evokuje související prekoncepty. Těmi jsou různé asociace na environmentální tématiku, negativní a pozitivní postoje k environmentalistice. Součástí prekonceptů jsou i očekávání od programu. Zajímavé je, že v očekávání se objevují především výstupy programu (nejčastěji tř́́dění odpadů), ale nikoliv očekávání vlastního zapojení do ekologizace.

Další kategorie byly mnohem méně zastoupeny. Druhou nejsilnější byly Procesy. Nejčastěji byly zmiňovány exkurze, které děti podnikly. Pro skupinu dětí z jedné třídy byla nejsilnějším zážitkem aktivita, ve které pohřbívaly na školním pozemku odpady. Další kódy byly zastoupeny jen velmi malým počtem respondentů.

Kategorie výstupů byla př́liš málo zastoupená, abychom ji mohli dále členit. Zařadili jsme do ní tři výroky. Pokud na jejich základě můžeme o něčem uvažovat, tak je to jistá skepse k účinnosti programu a absence vlastního zapojení:

- do školy jsme dostali koše na třídění odpadu. Ale skoro nikdo ve škole odpad netrídí.

Obr. č.6: Analýza kategorie Vztahy v kontrolní skupině.

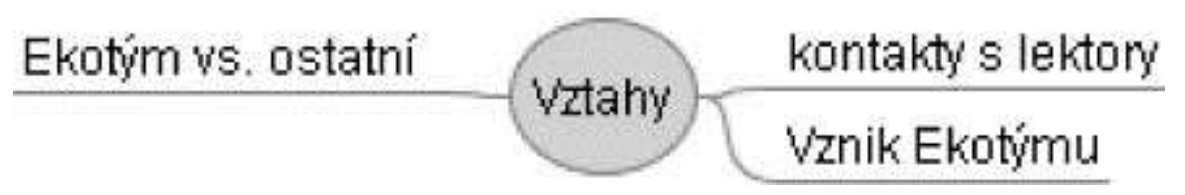

Do kategorie vztahů jsme zařadili sedm výroků. Jeden reflektoval setkání s koordinátory programu („ž̌e nám šli o tom povídat"), ostatní vyjadřují jisté napětí mezi členy Ekotýmu a zbytkem třídy, prípadně proces vzniku Ekotýmu. Zajímavé je, že reflexe často odráźí problémy ve vztazích ve třídě. 
Kvantifikace zastoupení jednotlivých kategorií

\begin{tabular}{|l|l|l|}
\hline Kategorie & Experimentální skupina & Kontrolní skupina \\
\hline Procesy & 71 & 17 \\
\hline Výstupy & 30 & 3 \\
\hline Nic / Prekoncepty & 21 & 114 \\
\hline Vztahy & 5 & 7 \\
\hline
\end{tabular}

Vzhledem k převažujícímu charakteru výzkumu a epizodičnosti zaznamenaných odpovědí nelze výsledky této části př́liš zobecňovat. Porovnání jednotlivých kategorií ukazuje očekávatelné rozdíly mezi oběma skupinami. Zatímco pro experimentální skupinu se program nejčastěji spojuje s netradičními aktivitami, členové kontrolní skupiny většinou neví, co si pod pojmem Ekoškola představit a uvádí své prekoncepty na environmentální tématiku.

Ani pro jednu skupinu nejsou dominantním zážitkem výstupy programu, členové experimentální skupiny si jich ale všímají. Zdá se, že program si většina žákư spojuje spíše s jeho aktivitami, které zažívají jako obohacení běžné výuky.

Získání titulu Ekoškola roku zaznamenali žáci příslušné školy jako prestižní událost, což mưže mít pozitivní dopady na jejich vztah ke škole.

V obou skupinách byla poměrně málo zastoupena rovina vztahů mezi spolužáky či žáky a pedagogy. Pokud se objevila, byla často spojena s negativními konotacemi naznačujícími určité napětí ve vztazích mezi členy Ekotýmu a zbytkem třídy nebo mezi žáky a pedagogy.

\section{Interpretace a doporučení}

\section{Limity výzkumu}

Všechny interpretace a výsledky evaluace uvedené $v$ tomto textu je třeba brát s vědomím následujících limitů:

Zkoumaný vzorek je menší, než je doporučovaná velikost pro vymezenou množinu. Současně mohla být reprezentativnost vzorku zkreslena nižší návratností dotazníků (zhruba 40 procent škol v obou skupinách). Přestože nejpravděpodobnějším důvodem škol pro odmítnutí účasti ve výzkumu byl nedostatek času na konci školního roku a vypadnutí dalších škol bylo zapříčiněno neaktuálními kontakty na školní koordinátory programu ${ }^{4}$, nelze zcela vyloučit, že se některé školy nezapojily i z jiných důvodu, např. $z$ obav z výsledků.

- Vzorek je tvořený žáky sedmých tříd základních škol. Výsledky proto nevypovídají o žácích mladších či starších. Zejména srovnání s prvním stupněm a střední školou by mohlo přinést odlišné výsledky.

- Výzkum vypovídá o chování, dovednostech, postojích a znalostech žáků pouze ve sledovaných kategoriích. Jeho výsledky proto nelze zobecňovat na

\footnotetext{
4 Šest škol ze základní množiny pro kontrolní skupinu se ani opakovaně nepodařilo kontaktovat.
} 
všechny kategorie odpovědného environmentálního chování, všechny relevantní dovednosti a znalosti akčních strategií či postoje k životnímu prostředí.

- Při dotazníkovém šetření nelze vyloučit stylizaci žáků do očekávaných žádoucích odpovědí, stejně jako neporozumění způsobené odlišnými konotacemi, které respondenti přisuzují vybíraným hodnotám (response bias).

- Některé hypotézy byly ověřovány jedinou otázkou. Zejména pocitóvanou spokojenost ve škole a míru partnerství s pedagogy je třeba dále zkoumat navazujícím kvalitativním šetřením.

- Část respondentů vynechala odpovědi na jednu či více otázek. Přestože byli $\mathrm{z}$ hodnocení př́slušné části dotazníku vyřazeni, mohlo dojít $\mathrm{k}$ určitému zkreslení výsledných dat (sample bias).

\section{Hlavní zjištění}

Účastníci programu Ekoškola ze škol, které dostaly zelenou vlajku...

- se chovají k životnímu prostředí šetrněji, než ostatní žáci, třídí častěji odpad, účastní se dobrovolných akcí pro přírodu či dobrovolných sbírek, šetří vodou a na nakupování si častěji berou vlastní tašky;

- častěji než ostatní žáci sdílí pocit, že mají možnost svým jednáním ovlivňovat stav životního prostředí;

- mají vyšší míru znalostí o odpovědném environmentálním chování v oblasti ekomanagementu;

- působí ve svém okolí jako názoroví vůdci, kteří doma i s kamarády diskutují o problémech životního prostředí.

Nebylo prokázáno, že by program Ekoškola měl vliv na

- environmentální akční dovednosti žáků;

- rozvoj partnerské spolupráce mezi žáky a pedagogy;

- zlepšení školního klimatu pocitóvaného žáky.

Nebylo rovněž prokázáno, že program Ekoškola

- působí odlišně na chlapce a na dívky. výuku.

Účastníci program nejčastěji vnímají jako zajímavé aktivity obohacující běžnou školní

\section{Diskuse}

Evaluace naznačila, že program Ekoškola pravděpodobně ovlivňuje odpovědné environmentální chování žáků v oblasti ekomanagementu. Nabízí se otázka, zda by míra proenvironmentálního chování nebyla ovlivněna ještě výrazněji, pokud by žáci současně rozvinuli relevantní akční dovednosti. Všechny otázky ve škále chování směřovaly k poměrně jednoduchým činnostem, které stojí na znalostech toho, "co je správné". Jiné formy proenvironmentálního chování mohou vyžadovat dovednosti, které žáci nemají.

Mizivé skóre, které žáci $v$ této části prokázali, kontrastuje $s$ metodikou celého programu. Zdá se, že $z$ nějakého důvodu nedochází ke specifickému transferu mezi aktivitami programu a životem žáků. 
Podle Gasse (1985) Ize transfer posílit pomocí cílené práce se skupinou, izomorfizace učící zkušenosti s prostředím odpovídajícím životu žáků, průběžného rozvíjení reflektivních dovedností žáků a internalizace učení. V doporučeních pro práci se skupinou se objevuje např. společná dohoda o cílech, delegování části odpovědnosti na žáky.

V metodice Ekoškoly je část těchto doporučení obsažena, některá ale možná zůstávají nevyužita. Určitou slabinou programu je možná práce se skupinou na úrovni třídy a související změny školního étosu směrem $k$ participativnějším formám výuky. Tomuto vysvětlení by odpovídaly i další překvapivé nálezy evaluace, totiž nedoložený vliv na míru spokojenosti dětí ve škole a nenaměřený rozdíl v míře partnerství s pedagogy ve srovnání s kontrolní skupinou. Rovněž analýza nejsilnějších zážitků se zaměřovala především na netradiční aktivity spojené s programem, než na prožitek vlastního zapojení nebo na vztahy se spolužáky a pedagogy; některé reflexe z kategorie vztahů odrážely spíše negativní zkušenosti nebo napětí mezi členy Ekotýmu a ostatními žáky.

Program vznikl v jiném kulturním prostředí a je možné, že jeho metodika předpokládá jiný způsob práce s žáky, než je obvyklý v České republice. Pokud program vstupuje do autoritativního školního prostředí, ve kterém není obvyklé formovat skupinu a rozvíjet její schopnost spolupracovat, může mu hrozit, že se stane programem nadšené skupiny, aktivního učitele za omezeného zájmu žáků mimo Ekotým, pro které je program především sledem netradičních aktivit a sumou znalostí, které se v nich naučí.

Zajímavou otázkou jsou faktory ovlivňující přihlášení žáků do Ekotýmu. V analýze nejsilnějšího prožitku kontrolní skupiny jsme viděli, že mnohé prekoncepty žáků jsou velice vágní a $v$ některých př́padech i negativní. Pokud se do práce $v$ Ekotýmu zapojí pouze pozitivně zaujatí žáci, hrozí zde riziko, že výchovné efekty programu budou koncentrovány na zainteresované žáky, zatímco ostatní zůstanou stranou. Do sestavení Ekotýmu navíc mohou vstupovat i vztahy ve skupině či jiné faktory (obliba učitele atd.). Provedená měření ale nepotvrdila, že by členové Ekotýmu ze škol se zelenou vlajkou měli vyšší míru znalostí než jejich ostatní kolegové.

Poslední otázka souvisí se začleněním programu do celého environmentálního kurikula školy. Program úspěšně rozvíjí některé proměnné se vztahem $\mathrm{k}$ odpovědnému environmentálnímu chování a posiluje také četnost vymezené množiny proenvironmentálního chování z oblasti ekomanagementu, ovlivňuje také postavení žáků jako názorových vůdců $v$ otázkách životního prostředí. Výzkum se nezaměřoval na další oblasti proenvironmentálního chování, tj. spotřebitelské chování, politické akce a právní akce. Program se také nezaměřuje na další důležité proměnné, jako jsou zejména environmentální senzitivita a komplexní porozumění environmentálním problémům. Pokud školy usilují o mnohostranný posun $v$ proenvironmentálním chování žákù, měly by Ekoškolu doplnit jiným programem či programy, které se na tyto chybějící oblasti zaměřují. Mưže být předmětem dalších experimentů pokusit se najít optimální kombinaci programů s maximálním synergickým efektem na chování žáků.

\section{Doporučení k dalším výzkumům}

Vzhledem k uvedeným limitům provedené evaluace doporučujeme zaměřit se v dalších evaluačních šetřeních na analýzu následujících otázek:

- Jaké jsou vztahy ve tř́dě, která získala zelenou vlajku? Jak tyto vztahy ovlivňují realizaci programu a jak jsou programem ovlivňovány?

- Jakým způsobem souvisí efektivita programu s existujícími normami skupiny?

- Jaké je postavení členů Ekotýmu ve třídě? Jak nezapojení žáci jejich práci na projektu hodnotí? Jak se liší environmentální prekoncepty členů Ekotýmu v době jeho vzniku od prekonceptů nezapojených spolužákư? 
- Vnímají pedagogové míru své spolupráce se žáky stejně či odlišně?

- Jak se liší výstupy programu na úrovni prvního, druhého a třetího stupně škol?

- Ovlivňuje Ekoškola i jiné proměnné, než byly analyzovány $v$ evaluaci? Jaký je její vliv na porozumění environmentálním problémům?

- Jak se liší výstupy škol, které kromě Ekoškoly realizují ještě jiné programy environmentální výchovy od těch, které realizují pouze Ekoškolu?

\section{Závěr}

Cílem evaluace bylo analyzovat teorii programu Ekoškola vyhodnocením jeho výstupů na úrovni učení a transferu. Evaluace ukázala, že program ve vymezené oblasti zvyšuje proenvironmentální chování žáků a související postoje a znalosti.

Evaluace nepotvrdila, že by program významněji ovlivňoval žáky $v$ rovině dovedností nebo že by pozitivně ovlivňoval školní klima. Tyto skutečnosti považujeme za významné zjištění a domníváme se, že spolu vzájemně souvisí.

Mnohé skutečnosti nebylo možné zvolenou formou výzkumu do hloubky prozkoumat. Předpokládáme proto realizaci navazujícího kvalitativního výzkumu, který by se měl zaměřit na vytipované oblasti, související např. s vlivem programu na vztahy ve skupině a vztahy pedagogů se žáky. Další výzkumy by se měly také zaměřit na analýzu výstupů programu pro mladší a starší žáky.

Je možné, že realizace programu $v$ českých podmínkách přináší určitá specifika související s tradicemi českého školství a že by bylo vhodné jej pro posílení účinnosti podpořit předchozím zařazením jiných programů či bloků aktivit.

Program Ekoškola významně přispívá k dosahování obecných cílů environmentální výchovy a je pravděpodobně jedním z nejlépe postavených programů realizovaných v České republice. Svým rámcem odpovídá současným trendům $v$ environmentální výchově, zdưrazňujících aktivní zapojení žáků na projektech s konkrétním výstupem, participaci žáků a pedagogů a propojení školy s místní komunitou. Lze doufat, že se program rozšírí a stane se významnou částí školních vzdělávacích programů českých škol.

\section{Literatura}

- Barch, B., Duvall, J., Higgs, A., Wolske, K., \& Zint, M. (2007). Planning and Implementing an EE Evaluation. . Retrieved from http://66.135.39.45:7080/meera-dev/knowledge-base/planan-ee-evaluation/

- Does Your Project Make a Difference? (2007). Sydney: Department of Environment and Conservation. Retrieved from http://www.environment.nsw.gov.au/resources/community/projecteval04110.pdf

- Ecosystem Management Iniatiative. Measuring Progress. An Evaluation Guide for Ecosystem and Community-based Projects. Ver. 3.0 (2004). : Ecosystem Management Initiative; School of Natural Resources and Environment; University of Michigan. Retrieved from http://www.snre.umich.edu/emi/evaluation/

- Emmons, K. M. (1997). Perspectives on Environmental Action: Reflection and Revision Through Practical Experience. Journal of Environmental Education,28(1), 34-44. http://dx.doi.org/10.1080/00958969709599105 
- FOUNDATION for Environmental Education. About Eco-Schools . : Foundation for Environmental Education. Retrieved from http://www.eco-schools.org/aboutus/aboutus.htm

- $\quad$ FOUNDATION for Environmental Education. Eco-Schools - a contribution to Local Agenda 21. An international programme for environmental and sustainability education, management and certification. (2003). : Foundation for Environmental Education. Retrieved from http://www.eco-schools.org/partners/2003brochure.pdf

- Frank, L. S. (2001). The Caring Classroom. Using Adventure to Create Community in the Classroom and Beyond. Madison: Project Adventure.

- Hammit, P., Freimund, W., Watson, A., Brod, R., \& Monz, C. (1995). Responsible Environmental Behavior: Metaphoric Transference of Minimum Impact Ideology. : Missoula Outdoor Learning Activities. Retrieved from http://www.nols.edu/resources/research/pdfs/porterhammittpaper.pdf

- Henton, M. (1996). Adventure in the Classroom. Dubuque: Kendal/Hunt Publishing.

- Hines, J. M., Hungerford, H. R., \& Tomera, A. N. (1986). Analysis and synthesi of Research on Responsible Environmental Behavior: A Meta-Analysis. The Journal of Environmental Education, 1986(7), 1-8.

- Hungerford, H. R., \& Volk, T. L. (1990). Changing learner behavior through environmental education. The Journal of Environmental Education. The Journal of Environmental Education, 21(3), 8-21. http://dx.doi.org/10.1080/00958964.1990.10753743

- Gass, M. A. Programming in the Transfer of Learning in Adventure Education. In . .

- Douglas, K., VOLK Trudi $L_{\prime \prime}$, \& HUNGERFORD Herold R, (1997). The Identification of Empirically Derrived Goals for Program Development in Environmental Interpretation. Journal of Environmental Education, 28(3), 24-34. http://dx.doi.org/10.1080/00958964.1997.9942826

- Kraft, R., \& SAKOFFS, Mitchell., (1985). The Theory of Experiential Education. Boulder: Association of Experiential Education.

- Kolb, D. (1984). Experiential Learning. Experience as The Source of Learning and Development. Englewood Cliffs, N.J: Prentice Hall.

- Mony, P. R. S. (2002). Assessing Environmental Literacy in Florida's 4-H Environmental Education Programme. : University of Florida. Retrieved from http://etd.fcla.edu/UF/UFE1001169/mony p.pdf

- O' Mahony, M. J., \& Fitzgerald, F. (2001). The Performance of the Irish Green-Schools Programme. Results of the Green-Schools Research Projects. : Environmental education unit. Retrieved from http://www.antaisce.org

- Pirrie, A., Elliot, D., McConnell, F., \& Wilinson, E. J. (2006). Evaluation of Eco-Schools Scotland. Glasgow: University of Glasgow.

- Sdružení TEREZA Ekoškola. Kritéria pro získání titulu Ekoškola . . Retrieved from http://ekoskola.cz/images/stories/materialy/kriteria.pdf

- Sdružení TEREZA Ekoškola. Seznam zapojených škol . . Retrieved from http://ekoskola.cz/index.php?option=com content\&task=view\&id=45\&Itemid=81

- Sdružení TEREZA Ekoškola. Příručka dobré praxe (2007). Praha: Sdružení TEREZA.

- Simmons, B. . Designing Evaluation for Education Projects. : Office of Education and Sustainable $\quad$ Development. Retrieved from http://wateroutreach.uwex.edu/use/documents/NOAAEvalmanualFINAL.pdf 
- W.K. Kellog Foundation . Logic Model Development Guide. Using Logic Models to Bring Together Planning, Evaluation, and Action (2004). Battle Creek: W.K. Kellog Foundation. Retrieved from http://www.wkkf.org 


\section{Poděkování:}

Za spolupráci na evaluaci děkuji Petrovi Danišovi, Petře Šimonové, Olze Lyžbické, Kristině Řešátkové a Jitce Krbcové se Střediska TEREZA, Michale Sakařové za pomoc se zpracováním dat a Magdě Nišponské z Technické univerzity $v$ Liberci za konzultace k použitým statistickým metodám.

\section{Příloha - Dotazník}

\begin{tabular}{|c|c|c|}
\hline 1 & Jsi: & $\begin{array}{l}\text { muž - žena } \\
\text { (Zakroužkuj správnou variantu) }\end{array}$ \\
\hline 2 & Kolik Ti je let & $\ldots \ldots \ldots \ldots \ldots($ doplň $)$ \\
\hline 3 & Jsi členem týmu Ekoškola: & $\begin{array}{l}\text { ANO - NE - nevím co to je } \\
\text { (Zakroužkuj správnou variantu) }\end{array}$ \\
\hline 4 & $\begin{array}{l}\text { Do jaké míry souhlasíš s následujícím tvrzením: } \\
\text { "Moje jednání má vliv na stav životního } \\
\text { prostředí." }\end{array}$ & $\begin{array}{l}\text { Zakroužkuj jednu možnost: } \\
\text { zásadně nesouhlasím } \\
\text { spíše nesouhlasím } \\
\text { nevím } \\
\text { spíše souhlasím } \\
\text { rozhodně souhlasím }\end{array}$ \\
\hline 5 & Třídíš ve škole odpad? & $\begin{array}{l}\text { Zakroužkuj jednu možnost: } \\
\text { Nikdy } \\
\text { Zřídka } \\
\text { Občas } \\
\text { Často } \\
\text { Pokaždé }\end{array}$ \\
\hline 6 & $\begin{array}{l}\text { Účastníš se ve svém volném čase akcí na ochranu } \\
\text { prírody a životního prostředí (úklid okolí, finanční } \\
\text { sbírky, atd.)? }\end{array}$ & $\begin{array}{l}\text { Zakroužkuj jednu možnost: } \\
\text { Nikdy }\end{array}$ \\
\hline
\end{tabular}




\begin{tabular}{|c|c|c|}
\hline & & $\begin{array}{l}\text { Zřídka } \\
\text { Občas } \\
\text { Často } \\
\text { Pokaždé, když je přiležitost }\end{array}$ \\
\hline 7 & Vypínáš vodu během čištění zubů? & $\begin{array}{l}\text { Zakroužkuj jednu možnost: } \\
\text { Nikdy } \\
\text { Zřídka } \\
\text { Občas } \\
\text { Často } \\
\text { Pokaždé }\end{array}$ \\
\hline 8 & Vypínáš doma po ukončení práce počítač? & $\begin{array}{l}\text { Zakroužkuj jednu možnost: } \\
\text { Nikdy } \\
\text { Zřídka } \\
\text { Občas } \\
\text { Často } \\
\text { Pokaždé }\end{array}$ \\
\hline 9 & Když odcházíš z místnosti, zhasneš? & $\begin{array}{l}\text { Zakroužkuj jednu možnost: } \\
\text { Nikdy } \\
\text { Zřídka } \\
\text { Občas } \\
\text { Často } \\
\text { Pokaždé }\end{array}$ \\
\hline 10 & Piješ vodu z kohoutku? & $\begin{array}{l}\text { Zakroužkuj jednu možnost: } \\
\text { Nikdy } \\
\text { Zřídka } \\
\text { Občas } \\
\text { Často } \\
\text { Pokaždé }\end{array}$ \\
\hline
\end{tabular}




\begin{tabular}{|c|c|c|}
\hline 11 & $\begin{array}{l}\text { Nosíš si do obchodu na nákup vlastní tašku nebo } \\
\text { batoh? }\end{array}$ & $\begin{array}{l}\text { Zakroužkuj jednu možnost: } \\
\text { Nikdy } \\
\text { Zřídka } \\
\text { Občas } \\
\text { Často } \\
\text { Pokaždé }\end{array}$ \\
\hline 12 & $\begin{array}{l}\text { Bavil ses s někým za poslední měsíc o životním } \\
\text { prostředí? }\end{array}$ & $\begin{array}{l}\text { Zakroužkuj na každé řádce jednu } \\
\text { možnost } \\
\text { Doma: ANO - NE - NEVÍM } \\
\text { S kamarády: ANO - NE - NEVÍM }\end{array}$ \\
\hline 13 & $\begin{array}{l}\text { Snažil ses za poslední měsíc někoho přesvědčit, } \\
\text { aby se choval šetrněji k životnímu prostředí? }\end{array}$ & $\begin{array}{l}\text { Zakroužkuj na každé řádce jednu } \\
\text { možnost } \\
\text { Doma: ANO - NE - NEVÍM } \\
\text { S kamarády: ANO - NE - NEVÍM }\end{array}$ \\
\hline 14 & $\begin{array}{l}\text { Nejvíc vody se v běžné domácnosti spotřebuje při } \\
\text { praní. Je to pravda? }\end{array}$ & ANO - NE - NEVÍM \\
\hline 15 & $\begin{array}{l}\text { Nápoje v plechovce jsou z hlediska životního } \\
\text { prostředí šetrnější, než v PET láhvi. Je to pravda? }\end{array}$ & ANO - NE - NEVÍM \\
\hline 16 & $\begin{array}{l}\text { Na často sekaných zahradách typu "anglický } \\
\text { trávník" najdeme méně rostlinných a živočišných } \\
\text { druhů, než na nepravidelně udržovaných } \\
\text { pozemcích. Je to pravda? }\end{array}$ & ANO - NE - NEVÍM \\
\hline 17 & $\begin{array}{l}\text { Z hlediska spotřeby energie je lepší si vodu na } \\
\text { špagety uvařit v rychlovarné konvici, než na } \\
\text { plotýnce elektrického sporáku. Je to pravda? }\end{array}$ & ANO - NE - NEVÍM \\
\hline 18 & $\begin{array}{l}\text { Do jaké míry si myslíš, že Tě učitelé v } \\
\text { rozhodování o životě školy berou jako partnera? }\end{array}$ & $\begin{array}{l}\text { Zakroužkuj jednu možnost: } \\
\text { Nikdy } \\
\text { Zřídka } \\
\text { Občas } \\
\text { Často } \\
\text { Pokaždé }\end{array}$ \\
\hline
\end{tabular}




\begin{tabular}{|c|c|c|}
\hline 19 & Jak se ve škole cítíš? & $\begin{array}{l}\text { Zakroužkuj jednu možnost: } \\
\text { Velmi špatně } \\
\text { Spíše špatně } \\
\text { Ani dobře, ani špatně } \\
\text { Spíše dobře } \\
\text { Velmi dobře }\end{array}$ \\
\hline 20 & $\begin{array}{l}\text { Představ si následující situaci: Tvoji rodiče } \\
\text { dostanou účet za elektřinu. Jsou nespokojení, že } \\
\text { musí zaplatit spoustu peněz, protože jste měli } \\
\text { velkou spotřebu. Jaký postup bys volil k tomu, } \\
\text { abyste svoji spotřebu snížili? }\end{array}$ & (Odpověz prosím ve 3-6 větách.) \\
\hline 21 & $\begin{array}{l}\text { A tohle je poslední otázka: Když se mluví o } \\
\text { Ekoškole, jaký nejsilnější zážitek / moment se Ti } \\
\text { vybaví? }\end{array}$ & (Odpověz prosím ve 3-6 větách.) \\
\hline
\end{tabular}


Časopis Envigogika vydává Centrum pro otázky životního prostředí UK. Vývoj časopisu je podpořen projektem OP VK Mezioborová sít udržitelného rozvoje.

Více najdete na internetových stránkách projektu mosur.czp.cuni.cz
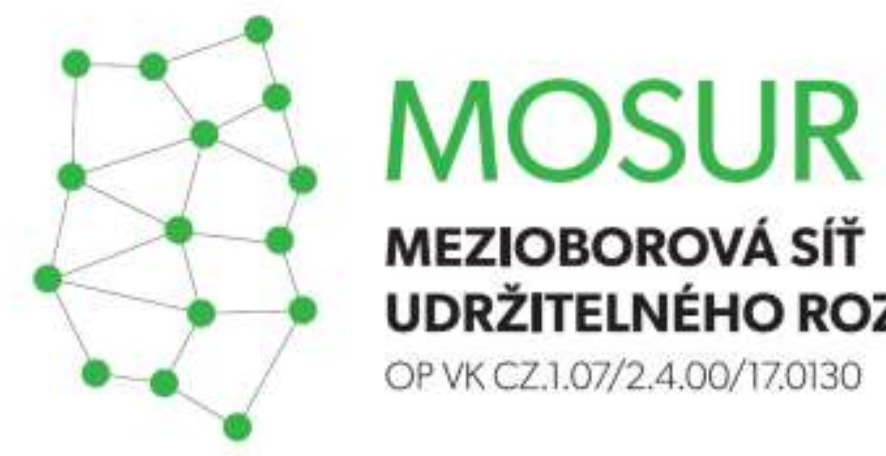

\section{MEZIOBOROVÁ SÍT} UDRŽITELNÉHO ROZVOJE

OP VK CZ.1.07/2.4.00/17.0130
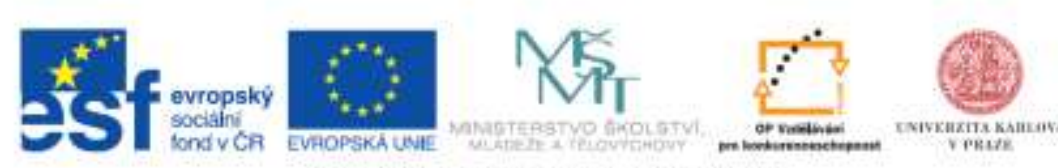

INVESTICE DO ROZVOUE VZDELAVANI 